\title{
Huge right atrial thrombus after discontinuation of anticoagulant therapy in atrial fibrillation
}

\author{
Jens Sundbøll, ${ }^{1}$ Morten Schmidt, ${ }^{2}$ Erik Lerkevang Grove ${ }^{1}$
}

'Department of Cardiology, Aarhus University Hospital, Skejby, Aarhus, Denmark ${ }^{2}$ Department of Clinical Epidemiology, Aarhus University Hospital, Skejby, Aarhus, Denmark

\section{Correspondence to} Dr Jens Sundbøll, jenssundboll@gmail.com

Accepted 20 April 2014

\section{$-1$}

To cite: Sundbøll J, Schmidt M, Grove EL. BMJ Case Rep Published online: [please include Day Month Year] doi:10.1136/bcr-2014204999

\section{DESCRIPTION}

An 88-year-old woman with a 1-year history of atrial fibrillation was admitted to the department of cardiology following syncope. At the time of admission, the patient had atrial fibrillation with a heart rate of $80-100 \mathrm{bpm}$ and was diagnosed with ortostatic hypotension and carotid hypersensitivity syndrome on carotid sinus massage. Owing to recent falling accidents, it was chosen to discontinue the patient's vitamin $\mathrm{K}$ antagonist treatment to prevent fall-related bleeding.

One month later, she was followed up in the outpatient clinic. We performed an echocardiography revealing a huge $(>8 \mathrm{~cm})$ right atrial thrombus prolapsing across the tricuspid valve (figure 1 and video 1). Surgical treatment was considered contraindicated because of the patient's age and comorbidity. Instead, treatment of the thrombus with low molecular weight heparin (dalteparin) was initiated.

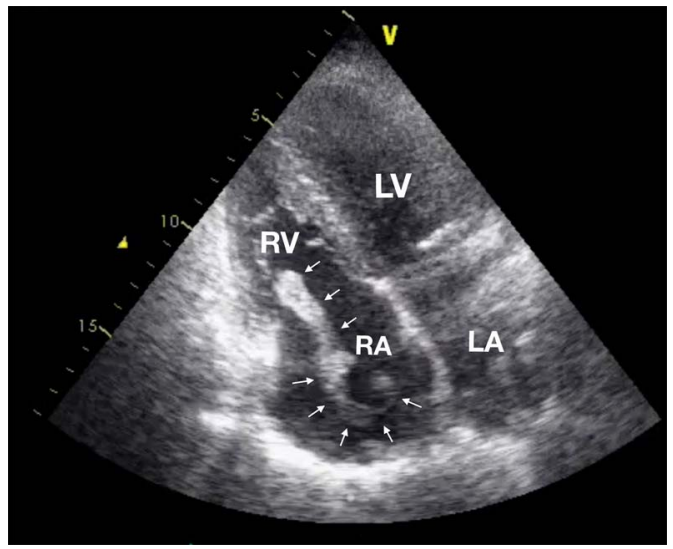

Figure 1 Right atrial thrombus prolapsing through the tricuspid valve (arrows). $R A$, right atrium; $R V$, right ventricle; $L A$, left atrium; $L V$, left ventricle.

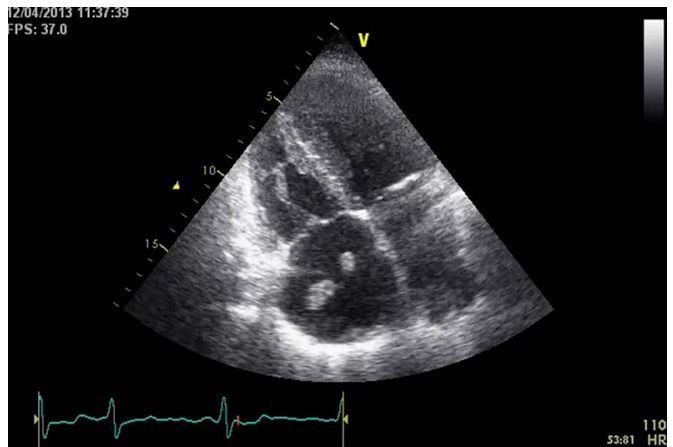

Video 1 Right atrial thrombus prolapsing through the tricuspid valve. The thrombus has a typical serpiginous shape.
The patient had a $\mathrm{CHA}_{2} \mathrm{DS}_{2}$-VASc score of 6 , which corresponds to an approximately $10 \%$ annual stroke risk, ${ }^{2}$ and thus strongly supports initiation of anticoagulant therapy. The HAS-BLED score was elevated at 5 . However, this does not contraindicate anticoagulant therapy, but merely suggests a more careful follow-up regimen on initiation of treatment. ${ }^{2}$

Accidental falls in patients with atrial fibrillation is a common clinical challenge. Physicians are often reluctant to prescribe anticoagulant therapy for elderly patients with atrial fibrillation whom they deem at risk of falling. However, risk of bleeding is often negligible compared with the risk of thromboembolism and initiation of anticoagulant therapy in these patients should primarily be based on the $\mathrm{CHA}_{2} \mathrm{DS}_{2}$-VASc score and not on patients' propensity to fall. ${ }^{3}$

\section{Learning points}

Accidental falls in patients with atrial fibrillation is a common clinical challenge.

- Patients' propensity to fall should not be a crucial factor in the decision to prescribe anticoagulant therapy in patients with atrial fibrillation.

- The $\mathrm{CHA}_{2} \mathrm{DS}_{2}$-VASc score should be used to select patients with atrial fibrillation for anticoagulant therapy whereas the HAS-BLED score, if concurrently elevated, advises caution, but does not contraindicate initiation of anticoagulant therapy.

Contributors JS wrote the initial draft. JS and ELG collected the patient data (pictures and patient history). JS, MS and ELG reviewed the literature, critically revised the manuscript for important intellectual content and approved the final version.

\section{Competing interests None.}

Patient consent Obtained.

Provenance and peer review Not commissioned; externally peer reviewed.

\section{REFERENCES}

1 Chartier L, Bera J, Delomez M, et al. Free-floating thrombi in the right heart: diagnosis, management, and prognostic indexes in 38 consecutive patients. Circulation 1999;99:2779-83.

2 Camm AJ, Lip GY, De Caterina R, et al. 2012 focused update of the ESC Guidelines for the management of atrial fibrillation: an update of the 2010 ESC Guidelines for the management of atrial fibrillation. Developed with the special contribution of the European Heart Rhythm Association. Eur Heart J 2012;33:2719-47.

3 Man-Son-Hing M, Nichol G, Lau A, et al. Choosing antithrombotic therapy for elderly patients with atrial fibrillation who are at risk for falls. Arch Intern Med 1999;159:677-85. 


\section{Images in...}

Copyright 2014 BMJ Publishing Group. All rights reserved. For permission to reuse any of this content visit http://group.bmj.com/group/rights-licensing/permissions.

BMJ Case Report Fellows may re-use this article for personal use and teaching without any further permission.

Become a Fellow of BMJ Case Reports today and you can:

- Submit as many cases as you like

- Enjoy fast sympathetic peer review and rapid publication of accepted articles

- Access all the published articles

- Re-use any of the published material for personal use and teaching without further permission

For information on Institutional Fellowships contact consortiasales@bmjgroup.com

Visit casereports.bmj.com for more articles like this and to become a Fellow 